\title{
A Framework of Business Process Re-engineering Factors and Organizational Performance of Nigerian Banks
}

\author{
Kabiru Jinjiri Ringim (Corresponding author) \\ College of Business, Universiti Utara Malaysia \\ Block R 003, Kolej Maybank residential hostels, Sintok 06010, Malaysia
}

Tel: 60-17-525-2975 E-mail: kabirujinjiri@yahoo.com

Mohd Rizal Razalli

School of Operations Technology Management and Logistics, College of Business, Universiti Utara Malaysia 06010 Sintok, Kedah, Malaysia

Tel: 60-19-577-7273 E-mail: rizal@uum.edu.my

\author{
Norlena Hasnan \\ School of Operations Technology Management and Logistics, College of Business, Universiti Utara Malaysia \\ 06010 Sintok, Kedah, Malaysia \\ Tel: 60-12-436-0105 E-mail: norlena@uum.edu.my
}

Received: November 17, 2011

Accepted: December 21, $2011 \quad$ Published: April 1, 2012

doi:10.5539/ass.v8n4p203

URL: http://dx.doi.org/10.5539/ass.v8n4p203

\begin{abstract}
The aims of this paper is to present a framework on the data collected regarding our research study on Effect of BPR factor on organization performance with moderating role of Information technology. A survey method was used to administer 560 questionnaires to Nigerian banks (Commercial, Microfinance and Primary mortgage finance). Data screening and cleaning was conducted to enable satisfy the assumptions of multivariate analysis. Therefore, the assessment of the missing data, outliers, normality, linearity, and multicollinearity were performed. In addition, factor analysis (PCA) was conducted with help of Statistical Package for Social Science (SPSS). The results were found to meet the requirement for multivariate analysis.

Keywords: BPR factors, Organization performance, Information technology capability, Data cleaning and screening, Nigerian banks

\section{Introduction}

The quality and meaningful result in multivariate analysis depend on the initial data screening exercise and many researchers tend to overlook it because of work load attached to it (Hair, Black, Babin, \& Anderson, 2010). Hence, the significance of data cleaning and screening exercise need not be over-emphasized as abandoning this initial stage of data examination would affect the quality output. Tabachnick \& Fidell, (2007) suggested proof reading of the original data against the data keyed into computer. But, having large data proof reading exercise would be difficult and monotonous. In this situation, the need to use computer software such as SPSS is critical. All hidden errors in data which cannot easily be seen would be revealed (Hair et al., 2010). By conducting data examination, the researcher stand the chance to understand the inter relationship among the variables and meet the assumption of multivariate data analysis. Therefore, the aim of this paper is to explain the relationship between business process reengineering and organizational performance as well as to present the procedure for conducting the data cleaning and screening, missing values, response bias, outliers, principal component analysis, normality, linearity, multicollinearity, homoscedasticity, correlation and reliability test.
\end{abstract}




\section{Literature Review}

The Information Systems literature on BPR can be classified into four parts (Thong, Yap, \& Seah, 2000). The first part examined lessons learned from BPR approaches which are case studies on critical success factors (Ahmad, Francis, \& Zairi, 2007; Aregbeyen, 2011; Broadbent, Weill, \& St.Clair, 1999; Caron, Jarvenpaa, \& Stoddard, 1994; Davenport \& Beers, 1995; El-Sawy, 1997; Herzog, Polajnar, \& Tonchia, 2007; Sarker, Sarker, \& Sidorova, 2006). The second research team focuses mainly on the inter-organizational aspects of BPR (Abdolvand, Albadvi, \& Ferdowsi, 2008; Chatfield \& Bjorn-Andersen, 1997; Lee \& Clark, 1996; Ranganathan \& Dhaliwal, 2001; Riggins \& Mukhopadhyay, 1994; Tennat \& Wu, 2005). The third research stream investigates the effectiveness of BPR methodologies, tools and techniques (Datta, 1988; Dennis, Hayes, \& Daniels, 1999; Kettinger, Teng, \& Guha, 1997; Nissen, 2001; Yavas \& Yasin, 2001). The forth research focus that is most relevant to this study is aim at explaining the relationship between business process reengineering (process changes) and organizational performance, moderating role of IT capability. This gives rationale as to why BPR, supported by closely aligned IT, generated value for the firm.

Barua, Lee, \& Whinston, (1996) proposed the theory of business value complementarities based on the theory of complementarities suggests that the economic benefit of a factor increases with the use of its complementary factors. In the context of reengineering, IT allows for innovative business processes, new skills, and new organizational structures (Brynjolfsson \& Hitt, 2003). Hence, Barua \& Whinston, (1998) and Barua et al., (1996) argue that IT is complementary to organizational characteristics and processes, and that investments in IT are less likely to succeed if done in isolation. Devaraj \& Kohli, (2000) reported that IT investments contribute to a higher level of revenue when combined with BPR initiatives. However, Loveman, (1990) found no relationship between various IT ratios and performance measures for return on investment. Likewise, Sager, (1998) and Venkatraman \& Zaheer, (1990) reveal that IT has no impact on performance. Brynjolfsson, (1993) has suggested that researchers should look beyond conventional productivity. Hence, Bhatt \& Grover, (2005); Tippins \& Sohi, (2003) started to include IT capabilities in their IT studies and explored the link between various dimensions of IT such as IT knowledge, IT operations, IT object, relationship infrastructure and IT business experience on organizational performance. Finding from their study showed that IT capabilities enhance organizational performance (Powell \& Dent-Micallef, 1997; Santhanam \& Hartono, 2003). In addition, findings from I.T studies conducted by researchers Adam (1993); Bharadwaj, (2000); Floyd \& Wooldridge, (1990); Santhanam \& Hartono, (2003) revealed that IT capabilities provide a basis of gaining competitive advantage and enhances organizational performance.

\section{Methodology}

The data analysis was carried out with help of descriptive and inferential statistics using SPSS version 16 software. Simple descriptive statistics, independent sample t- test, Mahalanobis distance, correlation, and reliability analysis were conducted. The sample of the study population was selected from 1,023 banks (Commercial, Microfinance and Primary Mortgage) registered with Central bank of Nigeria. Stratified cluster sampling techniques was used by selecting the banks covered randomly and the unit of analysis is organization. Hence, the senior managers, managers, HODs and top executive officers are the ones that responded to the questionnaire. Out of 560 administered questionnaires, only 460 were returned and 417 were usable for analysis

\section{Result Findings and Discussion}

\subsection{Response Rate}

The data for this study was collected from senior management, executives, managers and head of departments that represent the respective banks in Nigeria. In this study, attempts were made to increase the response rate such as by reminding the respondents through telephone call, SMS and self visits (Sekaran, 2003). As a result of this efforts, 460 questionnaires responded by the banks were returned out of the 560 questionnaires distributed by hand delivery to the respondent banks (commercial, microfinance and mortgage) in Nigeria. This makes the response rate of $82.14 \%$. Out of these 460 responses collected, 417 questionnaires were useable for further analysis making a valid response rate of $74.0 \%$. This response rate is considered adequate considering that, according to Sekaran, (2006) the response rate of 30\% is acceptable for surveys. Similarly, 417 responses are greater than Hair et al., (2010) suggested that for regression type of analysis, the sample size should fall between five and ten times the number of independent variables. Given the number of variables in this study, which is eight (8), would suggest a sample size of about 80 . Table 4.1 in appendix shows the distribution of required sample and total number of responses by each category of banks.

The data collection period took about five months. The follow up messages were made through text massages, phone calls and e-mails during the period. The data was keyed-in into SPSS (version 16.0) for further analysis. 
Forty three (43) questionnaires were excluded in the process of screening and cleaning the data. Errors were checked by analyzing the mean, standard deviation, minimum and maximum scores for all 417 cases on all variables.

\subsection{Personal Background of the Respondents}

The statistical frequency distribution of key variables in the questionnaires were objectively classified and presented in logical categories to reflect the originality of the study. Subsequently, the desired analytical tables were extracted for the proper data analysis as shown in appendix table 4.2. The descriptive analysis indicates that majority of the respondents in the organization were male (68\%). In terms of job title of the respondents, $35 \%$ are holding the responsibility of head of department, 30\% senior manager's, 20\% Deputy General Managers/Assistant General Manager's. Hence, these represent the majority of the targeted respondent for the study. Others include top management $(\mathrm{ED} / \mathrm{GM})$ that represents $16 \%$. The respondents represented their organizations that were categorized into three different types of banks viz: Commercial bank $4.3 \%$, of population sample (representing 75\% of registered Commercial bank with Central bank of Nigeria). Microfinance bank $74.8 \%$ of sample size (representing $35 \%$ registered Microfinance bank with central bank of Nigeria. and Primary mortgage banks were represented by $21 \%$ of the sample that accounted for $88.75 \%$ of registered primary mortgage bank with apex bank. As for the number of employees in these organizations, the highest was $60 \%$ for 1-50 numbers of employees including the outsourced personnel. This followed by $15 \%$ for above 2,000 employees inclusive of outsourced.

\subsection{Factor Analysis of the Research Instrument}

Factor analysis was conducted using a principal components analysis (PCA) with varimax rotation method to analyze the underlying structure of the inter-relationships among the variables into a set of common dimensions. This analysis will assess the measurement of convergent and discriminant validity. Convergent validity refers to the degree to which the scale correlate positively or in the same direction with other measures of the same construct. Discriminant validity refers to the degree to which the measurement scale does not correlate or distinct with other measures (Malhotra, 1999). PCA is a method that is used to help investigators represent a large number of relationships among interval-level variables in a simpler way. The method allows the computer to determine which, of a fairly large set of items, "hang together" as a group, or are answered most similar by the participants. The principal components analysis (PCA) was carried out for the items of the variables of this research work. The central idea of principal component analysis is to reduce the dimensionality of a data set in which there are a large number of inter-related variables, while retaining as much as possible of the variation present in the data set. This reduction is achieved by transforming to a new set of variables, the principal components, which are uncorrelated, and which are ordered so that the first few retain most of the variation present in all of the original variables. Computation of the principal components reduces to the solution of an eigenvalue problem for a positive semi-definite symmetric matrix. As for the sample size, a guideline by (Coakes \& Steed, 2003); Hair et al., (2010) indicates that a minimum of five subjects per variable are needed for factor analysis. In this study, with 8 variables, a sample size of 417 is higher than the minimum requirement of the desired cases for factor analysis. A sample size of more than 350 requires a factor loading of 0.30 to assess statistical significance (Hair et al, 2010). Hence, the minimum requirement for factor analysis was fulfilled.

\subsubsection{Dependent Variable - Organization performance (OP)}

Table 4.3 in the appendix shows the factor loadings and communality values for factor analysis of dependent variable (organization performance). At inception, the dependent variable was measured by 20 items in two dimensions was subjected to principal component analysis (PCA) using SPSS Version 16. Prior to performing PCA, the suitability of data for factor analysis was assessed. The factor loading of the items range from 0.770 to 0.984 with 10 items had been removed due to some reasons such as having low MSA value, low communalities value, loading less than 0.50 , and cross-loading. The ten (10) deleted items from the initial 20 items measurement of organization performance construct $(1,2,6,10,11,12,14,16,17$ and 19) were those items that indicated failure to fit well with other items in their components. Removing these items with low communality values had increased the total variance explain. Inspection of the correlation matrix revealed the presence of many coefficients of 0.3 and above. The Kaiser-Meyer-Olkim (KMO) measure of sampling adequacy was 0.885 exceeding the benchmark value of 0.60 . It shows that the sample size is adequate for factor analysis to be conducted. That is, the ratio of the sample size to the number of items is sufficient for factorability. On the other hand, the Bartlett's test of sphericity is statistically significance, supporting the factorability of the correlation matrix, as the p-value is 0.000 . This implied the adequacy of applying the factor analysis. Principal component analysis revealed the presence of three components with eigenvalue exceeding 1 . The three components 
extracted were named 1) operation cost reduction (OP20), 2) customer service relationship management (OP4), and 3) business operations efficiency (OP8). The percentages of the variance were $50.70 \%, 19.94 \%$, and $11.26 \%$ respectively.

The three-component solution explained a total of $81.90 \%$ of the variance. To aid in the interpretation of these three components, varimax rotation was performed. The first component was defined by five items related to operating cost. This includes interest payment (cost) on tenured fund, branches operational cost, cost of recovering bad loans, and provisional cost of having number of bad loans in the organization. The higher loadings will influence the name of the factor (Hair et al., 2010). The higher loadings were level of operating cost, interest cost of tenured fund and branches operating cost. Operating cost and interest cost are part of cost of doing business in organization (Hammer \& Champy, 1993). Hence, this factor was named as operation cost reduction. The second component was defined by three items namely customer relationship management, brand name, and customer service delivery. These items were related to customer service relationship management (Bontis, 1998; Bontis, Chua, \& Richardson, 2000; Khong \& Richardson, 2003; Kotler, 2003). Hence, Customer service management name was used. Finally the third component was represented by two items such as zero error of operational process, and market share in retail, consumer and corporate banking services. Zero error process is a category of efficient service delivery/speed (Hammer \& Champy, 1993). Hence, the factor was named Business operations efficiency.

\subsubsection{Moderating Variable - Information Technology Capability (I.T Capability)}

Table 4.3 in the appendix shows the factor loadings and community values of the results for factor analysis of information technology capability. At the beginning, the moderating variable was measured by 12 items in two dimensions, which were subjected to principal component analysis (PCA) using SPSS Version 16. Prior to the process of performing PCA, the suitability of data for factor analysis was assessed. The factor loading of the items range from 0.650 to 0.794 with 2 items been removed due to some reasons such as having low MSA value, low communality value, loading less than 0.50 , and cross-loading. The deleted items from the initial (1and 2 ) are those items that indicated a sign of non fit with other items in their components. Removing the non fit items that have low communality values had increased the total variance explain for this study. Inspection of the correlation matrix revealed the presence of many coefficients of 0.3 and above. The Kaiser-Meyer-Olkim (KMO) measure of sampling adequacy of 0.863 exceeding the bench mark value of 0.60 , this implied that, the sample size is adequate for factor analysis to be conducted. Also, the ratio of the sample size to the number of items is sufficient for factorability. On the other hand, the Bartlett's test of sphericity is statistically significance, supporting the factorability of the correlation matrix, as the p-value is 0.000 . This indicated the adequacy of applying the factor analysis. Principal component analysis revealed the presence of three components with eigenvalue exceeding 1. The three component extracted were named 1) I.T knowledge (IT Cap3), 2) I.T Operations (I.T Cap8), and 3) I.T objects (I.T cap11). The percentages of the variance were $39.81 \%, 11.64 \%$, and $10.55 \%$ respectively.

The three-component solution explained a total of $61.99 \%$ of the variance. To aid in the interpretation of these three components, varimax rotation was performed. The first component was defined by four items related to I.T knowledge. This includes professional qualification, I.T staff proactiveness in ebanking innovation, qualified trained expertise/consultant in computing, and regular training courses for IT staff. The higher loadings will influence the name of the factor (Hair et al., 2010). The higher loadings were professional qualification of IT engineers, proactive innovation in ebanking by I.T staff and qualified expertise/consultant. Professional qualification, expertise consultants and regular training of I.T staff can be viewed as skill knowledge in I.T computing (Tippins \& Sohi, 2003). Hence, this factor was named as I.T knowledge. The second component was defined by three items namely technology based link via local area network and wide area network on-line real time (LAN and WAN 24/7), link to branches through WAN, and minimal computer system down time. These items were related to I.T operations (Tippins \& Sohi, 2003). Hence, the original name was retained. Finally the third component was represented by three items such as organization IT policy in line with regulators guidelines, monitoring of customer's transaction by IT operations, and computerization of banking operations. I.T objects encompass the comprehensive procedures of operational processes/transactions and requirement for disclosures, oath of secrecy, confidentiality and management of customer's activities. Hence, the factor was named I.T Objects.

\subsubsection{Independent Variables: Business Process Re-engineering Factors (BPR Factors)}

The independent variables of this study are the BPR factors which includes: 1) Change Management - measured as uni-dimension, 2) BPR Project Management - uni-dimensional, 3) Top Management Commitment - one 
dimension, 4) Customer Focus - one dimension, 5) I.T Infrastructure - one dimension, 6) Process Redesign one dimension, 7) Financial Resources - one dimension, 8) Less bureaucratic structure - one dimension. At the beginning total items measuring the BPR factors were 56 items. These items and dimensions were analyzed using factor analysis to check for their validity. Using the criteria for conducting factor analysis as discussed in section 4.3 above. The analysis extracted nine components. In the process of getting these nine components, 27 items and one construct (Less bureaucratic structure) had to be deleted due to various reasons such as low communality value, loading less than 0.50 , and cross loading. Removing items with low communalities values increased the total variance explain. Inspection of the correlation matrix revealed the presence of many coefficients of 0.30 and above. The Kaiser-Meyer-Okin value was 0.750 , exceeding the recommended value of 0.6 (Kaiser, 1970, 1974) and the Bartlett's Test of Sphericity (Bartlett, 1954) reached statistical significance, supporting the factorability of the correlation matrix. Table 4.5 present the factor loadings and communality values for the result of factor analysis of independent variable of the study.

The number of final factors together with the number of items used to measure the particular variable is as follows:

1) I.T investment (IT Infra3) - 4 items

2) Strategy Alignment (Proj1) - 4 items

3) Customer Focus (CF4) - 3 items

4) Personnel commitment (TOP7) -3 items

5) Communication (CM8) -3 items

6) Training and education (CM3) - 3 items

7) Volume of financial activities (AFR5) - 4 items

8) Reward system (CM4) - 2 items

9) Strong capital base (AFR2) -2 items

As shown in the table 4.4, Principal Components analysis revealed the presence of nine components with eigenvalue exceeding 1 , explaining $16.127 \% ; 11.416 \% ; 8.274 \% ; 6.158 \% ; 5.974 \% ; 4.540 \% ; 4.270 \% ; 3.854 \%$ and $3.645 \%$ of the variance respectively. An inspection of the screeplot revealed a clear break after the ninth component. Using (Catell, 1966) scree test, it was decided to retain nine components for further investigation. To aid in the interpretation of these nine components, Varimax rotation was performed. The rotated solution revealed the presence of simple structure (Thurstone, 1947), with both components showing a number of strong loadings and all variables loading substantially on components. The nine factor solution explained a total of $64.259 \%$ of the variance, with component 1 contributing $16.127 \%$; component 2 contributing $11.416 \%$; component 3 contributing $8.274 \%$; component 4 contributing $6.158 \%$; component 5 contributing $5.974 \%$; component 6 contributing $4.540 \%$; component 7 contributing $4.270 \%$; component 8 contributing $3.854 \%$ and component 9 contributing $3.645 \%$ respectively.

The first factor was defined by four items and reflected the organization's investment in information technology to achieve proper IT integration, build effective IT infrastructure and redesign core process for efficient service delivery. Thus, this factor was named IT investment. The second factor was dominated by items relating to organization strategic initiative project that aligned with corporate policy. Therefore, this factor was named strategy alignment driven of reengineering project (Zairi \& Sinclair, 1995). The third factor was dominated by items relating to customer focus, which are oriented toward finding new ways of adding value to customer (Scherr, 1993). Thus, this factor was named Customer focus. The fourth factor consist of items pertaining to personnel capability to handle related changes recommended by consultant and consider process re-engineering as method to improve process performance in the organization, thus, this factor was named personnel commitment. The fifth factor consists of items related to communication for employee to accept positive changes by involving them in implementation of business process re-engineering. Therefore, the factor was named effective communication. The sixth factor was dominated by training and education of employees in newly introduced core processes for effective service delivery. Thus, this factor was named Training and education. The seventh factor consist of items related to organization volume of financial activities and making use of appropriate software technology to redesign processes thus, this factor was named volume of financial activities to customer. The eighth factor consists of items related to effective reward system that encourage employees to accept changes for improvement. Therefore, this factor was named reward system. The ninth factor consists of 
items related to organization adequate capital base to provide a cushion for risk asset and conduct profitable transaction. Therefore this factor was named strong capital base.

\subsection{Reliability Analysis}

The reliability test for each dimension emerged after factor analysis was conducted. Cronbach's alpha coefficient is widely used as a measure of reliability. A value of 0.7 in the Cronbach's alpha is considered adequate to ensure reliability of the internal consistency of the questionnaire(Nunnally, 1978). The Cronbach's alpha range from 0.60 to 0.99 for the variables in the questionnaire used for the study implies that the instrument is reliable. Flynn, Schroeder, \& Sakakibara, (1994) argued that a Cronbach's alpha of 0.6 and above was considered an effective reliability for judging a scale. The generally agreed lower limit for Cronbach's alpha may decrease to 0.60 in exploratory research (Hair et al., 2010). Hence, instrument has excellent reliability as far as internal consistency is concerned. That is, the instrument can give consistent results on the effect of business process reengineering factors on organizational performance of Nigerian banks.

\subsection{Modified framework and restatement of hypotheses}

The result of analysis indicated that hypothesis needs to be restated and referred to throughout the study. Prior to factor analysis major variables such as Change Management, BPR Project Management, Top Management Commitment, Customer Focus, I.T Infrastructure, Process redesign, Financial resources and Less bureaucratic structure were measured as uni-dimensional. However, after factor analysis they were found to be as follows: 1) Communication; 2) Training and Education; 3) Reward System; 4) Strategy Alignment; 5) Personnel Commitment; 6) Customer Focus; 7) I.T investment; 8) Volume of Financial Activities; 9) Strong Capital base.

The dependent variable (organizational performance) had merged into three dimensions: 1) Operational cost reduction; 2) Customer service management; 3) Business operations efficiency

While the moderating variable (I.T Capability) had merged into three dimensions: I.T Knowledge; 2) I.T Operations; 3) I.T Objects. The modified research model for the study is shown in figure 4.1.

\subsection{Preliminary Analysis}

Preliminary analysis includes: descriptive statistics for major variables and Inter-correlations of major variables.

\subsubsection{Missing Data}

On receiving the completed questionnaires, the research assistant checked and ensured that all questions were answered. Where any exception was discovered, the attention of the respondent was drawn to answer appropriately. Hence, this had assisted significantly in reducing the number of un-attended questions in the survey. After the collection stage, the data were keyed into SPSS software in two (2) trenches i.e. the early response and the late response. Preliminary descriptive statistics was run to further confirm identify if any the missing data exist or not. Hair et al., (2010) suggested that any case with more than $15 \%$ missing data observed should be deleted as long as the sample is adequate. This suggestion was in line with Tabachnick \& Fidell, (2007) that a case of missing data should be simply drop.

\subsubsection{Assessment of outliers}

The assessment of outliers is another important stage of data screening. The extreme case scores that might have a significant effect on the result either too high, too low or unique combination of values across several variables cases were deleted (Hair et al., 2010). Therefore, using multivariate analysis necessitate identification and treatment of outliers accordingly. Mahalanobis Distance $\left(\mathrm{D}^{2}\right)$ was used to identify and deal with outlying cases. The procedure is to run Mahalanobis in the SPSS and then compare the values with that of Chi-square table. These mean that any case with Mahalanobis value above is multivariate outliers and were deleted from further analysis.

\subsubsection{Presentation of Descriptive Statistics for Independent Variables}

The descriptive statistics shows the minimum and maximum scores, mean values and standard deviation of key variables in the questionnaires using the six Likert-scale criteria ranging from 1 to 6 . The mean scores for all variables were in the range of 4.74 to 5.08. Overall the mean for BPR factors variables were between the ranges of 4.78 and 4.96. These generally indicated that the bank managers agreed that their banks were implementing good BPR practices. The dependent variables were assessed using the Likert scale of 1(decrease significantly) to 6 (increase significantly) over the past three years. The mean score values indicated that most of the banks that participated in the study were doing well in terms of operating cost containment that improved their general performance as showed by the highest mean value of 4.98 with standard deviation of 1.106 . This followed by 
effective customer relationship management in service delivery that have a mean score of 4.95 , standard deviation of 0.903 and error free operational processes mean value of 4.74 with standard deviation of 0.933 .

\subsubsection{Tests for Violations of Assumptions for Multiple Regressions}

To achieve the underlying assumption of the Multiple Regression Analysis, the variables were checked for outliers, normality, linearity, multicollinearity and homoscedasticity in line with the analysis suggested by Hair et al., (2010) and Pallant (2001).

\subsubsection{Normality}

One of the approaches to assess the normality assumptions is through histogram residual plots. It refers to the shape of data distribution for an individual continuous variable and its correspondence to normal distribution. To meet the assumptions, the distribution of the plot needs to appear normally distributed. The ultimate objective of the research is to make inference, then, screening for normality is an important step in almost all multivariate analysis (Tabachnick \& Fidell, 2007). From figure 4.0 in appendix, it shows the normal histogram pictorially depicts that the normality assumption is achieved since all the bars of the histogram are close to a normal curve. On the other hand, the normal probability plot satisfied the homoscedasticity assumptions of the variance of the random error component since all the points lie along $45^{\circ}$ diagonal line. Similarly, the normality assumption for other variables was not violated

In addition the assumptions of Collinearity also need to be met. These assumptions apply to the independent variables, dependent variable, and the relationship between independent and dependent variables is linear. According to Hair et al., (2010), if the analysis does not show any non linear pattern to residuals, it is ensured that overall equation is linear and can be examined through residual plots. Meanwhile homoscedasticity implies equal variances of dependent variable at each observation of the independent variable and similarly can be examined from the histogram of the standardized residuals and the Q-Q plots (Hair et al., 2010). The assumption of independent implies that the samples are independent from one another. In this study, the independent assumption was met because the samples were randomly selected from the population.

\subsubsection{Linearity}

To check for linearity, this study used the residual scatter plot. If the assumptions are satisfied, the residuals should scatter around 0 or most of the scores shall concentrate in the centre along the 0 point (Flury \& Riedwyl, 1988). Figure 4.1 displayed the scattered plot between BPR factors and organization performance. The plot shows that the residual scores were concentrated at the centre along the zero $(0)$ point, thus, suggesting the linearity assumption was met. Similarly, it appeared that the other variables also demonstrated that the linearity assumption was not violated.

\subsubsection{Multicollinearity}

Multicollinearity is defined as the degree of correlation among independent variables. Independent variable is highly correlated (above 0.90 ) among themselves (Hair et al., 2010). Verifying the multicollinearity problem can be done through bivariate correlations of all the independent variables. In this study, multicollinearity has been examined between the independent variables (BPR Factors) using Pearson correlation. Multicollinearity increases the variance of regression coefficients and threatens to the validity of the regression equation. The values of Pearson correlations show the relationships between independent variables, and are a method for diagnosing multicollinearity (Allison, 1999). As noted by (Cooper \& Schindler, 2003) there is no definitive criterion for the level of correlation that constitutes a serious multicollinearity problem.

The general rule of thumb is that it should not exceed 0.75. Similarly, Allison (1999) and Cooper and Schindler (2003) indicated that correlations of 0.8 or higher are problematic. The result in the table shows no multicollinearity between independent variables because the Pearson correlation indicators for all independent variables are less than 0.7. Another approach is to look at the variance inflated factor (VIF) and tolerance value. It is generally believed that any variance inflation factor (VIF) exceeds 10 and tolerance value lower than 0.10 indicates a potential problem of multicollinearity (Hair et al., 2010). Table 4.5 in appendix shows the Tolerance and VIF values for independents variables

The result in Table 4.5 shows that multicollinearity does not exist among all independent variables because the Tolerance values are more than 0.10 and VIF values are less than 10. The result indicates that the study does not have any multicollinearity problem. The hierarchical regression was subjected to criticism because the interaction term leads to multicollinearity problem (Aiken \& West, 1991; Cohen \& Cohen, 1983; Frazier, Barron, \& Tix, 2004). As a result of centered mean, VIF and tolerance values were within acceptable required range. Thus multicollinearity was not a problem in this study. 


\subsubsection{Homoscedasticity}

Homoscedasticity is assumed when there is no pattern in the data distribution and residuals are scattered randomly around the horizontal line through 0 (Norusis, 1999). The assumption of homoscedasticity requires that the variance of the dependent variable is the same at all values of independent variable or constant variance of error term (Hair et al., 2010). Durbin-Watson can be used to test the independence of error terms (Norusis, 1999). The general rule of thumb is, if the Durbin-Watson value is between 1.50 and 2.50, the assumption of independence of the error terms is not violated (Norusis, 1999). The Durbin-Watson value of 1.938 in this study met the general rule of thumb, and assures the assumptions of independence of error terms is not violated.

\section{Conclusion}

As the missing values were checked, multivariate outlier had been deleted and data satisfy the normal distribution without any problem of non response bias, the data was fully screened and clean. Furthermore, the evaluation on assumptions of linearity, homoscedasticity, normality, independence of the error terms, and multicollinearity revealed no significant violation of assumption. Hence, it can be concluded that the data was ready for multivariate analysis.

\section{References}

Abdolvand, N., Albadvi, A., \& Ferdowsi, Z. (2008). Assessing readiness for business process reengineering. Business Process Management Journal, 14(4), 497-511. http://dx.doi.org/10.1108/14637150810888046

Adam, M. M., \& J, M. (1993). Measuring the organizational impact of information technology investment: An exploratory study. Journal of Management Information Systems, 10(1), 97.

Ahmad, H., Francis, A., \& Zairi, M. (2007). Business process reengineering: critical success factors in higher education. Business Process Management Journal, 13(3), 451-467. http://dx.doi.org/10.1108/14637150710752344

Aiken, L. S., \& West, S. G. (1991). Multiple regression: Testing and interpreting interactions. Newbury Park: Sage Publications.

Allison, P. (1999). Multiple regressions: A primer. CA: Pine Forge Press.

Aregbeyen, O. (2011). Business Reengineering and Organizational Performance in Nigeria: A Case Study of First Bank Nigeria Plc. International Business Management, 5(3), 151-158. http://dx.doi.org/10.3923/ibm.2011.151.158

Armstrong, J. S., \& Overton, T. S. (1977). Estimating Non response Bias in Surveys. Journal of Marketing Research, 14(3), 396-402. http://dx.doi.org/10.2307/3150783

Bartlett, M. (1954). A note on multiplying factors for various chi square approximations. Journal of the Royal Statistical Society, 16(series B), 296-298.

Barua, A., Lee, B., \& Whinston, A. (1996). The calculus of reengineering. Information Systems Research, 7(4), 409-428. http://dx.doi.org/10.1287/isre.7.4.409

Barua, A., \& Whinston, A. B. (1998). Complementarity based decision support for managing organizational design dynamics. Decision Support Systems, 22(1), 45-58. http://dx.doi.org/10.1016/S0167-9236(96)00059-0

Bharadwaj, A. S. (2000). A Resource-Based perspective on Information Technology capabilities and firm performance: an empirical investigation. MIS Quarterly, 24, 169. http://dx.doi.org/10.2307/3250983

Bhatt, G. D., \& Grover, V. (2005). Types of Information Technology Capabilities and their role in competitives Advantage: An Empirical Study. Journal of Management Information Systems, 22(2), 253-277.

Bontis, N. (1998). Intellectual capital: an exploratory study that develops measures and models. Management decision, 48(9), 63-67. http://dx.doi.org/10.1108/00251749810204142

Bontis, N., Chua, C. K., \& Richardson, S. (2000). Intellectual capital and business performance in Malaysian industries. Journal of Intellectual Capital. 1, 85-100. http://dx.doi.org/10.1108/14691930010324188

Broadbent, M., Weill, P., \& St.Clair, D. (1999). The implication of information technology infrastructure for business process redesign. MIS Quarterly, 23.

Brynjolfsson, E. (1993). The productivity paradox of information technology. Communication of the ACM, 42(4), 541-558. 
Brynjolfsson, E., \& Hitt, L. M. (2003). Computing productivity: Firm-level evidence. Review of Economics and Statistics, 85(4), 793-808. http://dx.doi.org/10.1162/003465303772815736

Caron, J. R., Jarvenpaa, S. L., \& Stoddard, D. B. (1994). Business reengineering at Cigna Corporation: Experiences and lessons learned from the first five years. MIS Quarterly, 18, 233-250. http://dx.doi.org/10.2307/249617

Catell, R. (1966). The scree test for number of factors. Multivariate Behavioural Research, 1, 245-276. http://dx.doi.org/10.1207/s15327906mbr0102_10

Chatfield, A. T., \& Bjorn-Andersen, N. (1997). The impact of IOS-enabled business process change on business outcomes: Transformation of the value chain of Japan Airlines. Journal of Management Information Systems, 14(1), 13-40.

Coakes, S. J., \& Steed, L. G. (2003). SPSS: Analysis without anguish. Sydney: John Wiley \& Sons.

Cohen, J., \& Cohen, P. (1983). Applied multiple regression/correlation analysis for behavioural science (2nd ed.). Erlbaum.

Cooper, D. R., \& Schindler, P. S. (2003). Business research methods (8th ed.). Boston: MA: McGraw Hill.

Datta, A. (1988). Automating the discovery of AS-IS business process models: Probabilistic and algorithmic approaches. Information Systems Research, 9(3), 275-301. http://dx.doi.org/10.1287/isre.9.3.275

Davenport, T. H., \& Beers, M. C. (1995). Managing information about processes. Journal of Management Information Systems, 12(1), 57-80.

Dennis, A. R., Hayes, G., \& Daniels, R. M. J. (1999). Business process modeling with group sup- port systems. Journal of Management Information Systems, 15(4), 115-142.

Devaraj, S., \& Kohli, R. (2000). Information technology payoff in the health-care industry: A longitudinal study. Journal of Management Information Systems, 16(4), 41-67.

El-Sawy, D. (1997). Business process reengineering do software tools matters? Paper presented at the Conference in Information Systems, Florida USA.

Floyd, S. W., \& Wooldridge, B. (1990). Path Analysis of the Relationship between competitive strategy, information technology and financial performance. Journal of Management Information Systems, 7(1), 47-64.

Flury, B., \& Riedwyl, H. (1988). Multivariate Statistics: A practical approach. London: Chapman and Hall. http://dx.doi.org/10.1007/978-94-009-1217-5

Flynn, B., Schroeder, R., \& Sakakibara, S. (1994). A framework for quality management research and an associated measurement instrument. Journal of Operations Management, 11, 339-366. http://dx.doi.org/10.1016/S0272-6963(97)90004-8

Frazier, P. A., Barron, K. E., \& Tix, A. (2004). Testing Moderator and Mediator Effects in Counselling Psychology Research. Journal of Counselling Psychology, 51(1), 115-134. http://dx.doi.org/10.1037/0022-0167.51.1.115

Hair, J., Black, W. C., Babin, B. J., \& Anderson, R. E. (2010). Multivariate data analysis (7th ed.). Upper saddle River, New Jersey: Pearson Education International.

Hammer, M., \& Champy, J. (1993). Reengineering the Corporation (1st ed.). USA: Harper Collins Inc.

Herzog, N., Polajnar, A., \& Tonchia, S. (2007). Development and validation of business process reengineering (BPR) variables; a survey research in Slovenian companies. International Journal of Production Research, 45(24), 5811-5834. http://dx.doi.org/10.1080/00207540600854992

Kaiser, H. (1970). A second generation little jiffy. Psychometrika, 35, 401-415. http://dx.doi.org/10.1007/BF02291817

Kaiser, H. (1974). An index of factorial simplicity. Psychometrika, 39(31-36). http://dx.doi.org/10.1007/BF02291575

Kettinger, W. J., Teng, J. T. C., \& Guha, S. (1997). Business process change: A study of methodology techniques, and tools. MIS Quarterly, 21(1), 55-80. http://dx.doi.org/10.2307/249742

Khong, K. W., \& Richardson, S. (2003). Business process reengineering in Malaysian banks and finance companies. Managing Service Quality, 13(1), 54-71. http://dx.doi.org/10.1108/09604520310456717

Kotler, P. (2003). Marketing Management (11th ed.). New Jersey: Prentice-Hall. 
Lee, H. g., \& Clark, T. H. (1996). Market process reengineering through electronic market system: Opportunities and challenges. Journal of Management Information Systems, 13(3), 113-136.

Loveman, G. (1990). An assessment of the Productivity impact on Information technologies. Sloan Management Review, MIT working paper.

Malhotra, N. (1999). Marketing Research: An applied orientation (3rd ed.). New Jersey: Prentice Hall.

Nissen, M. E. (2001). An experiment to assess the performance of a redesign knowledge system. Journal of Management Information Systems, 17(3), 25-43.

Norusis, M. J. (1999). Guide to data analysis. New Jersey: Prentice Hall.

Nunnally, J. C. (1978). Psychometric Theory (2 ed.). New York: McGraw Hill.

Pallant, J. (2007). SPSS Survival Manual: A Step by Step Guide to Data Analysis using SPSS for Windows (3rd ed.). England: McGraw Hill Open University Press.

Powell, T. C., \& Dent-Micallef, A. (1997). Information Technology as Competitive Advantage: The Role of Human, Business, and Technology Resources. Strategic Management Journal, 18(5), 375-405. http://dx.doi.org/10.1002/(SICI)1097-0266(199705)18:5<375::AID-SMJ876>3.0.CO;2-7

Ranganathan, C., \& Dhaliwal, J. S. (2001). A survey of business process reengineering practices in Singapore. Information and Management, 39(2), 125-134. http://dx.doi.org/10.1016/S0378-7206(01)00087-8

Riggins, F. J., \& Mukhopadhyay, T. (1994). Interdependent benefits from interorganizational systems: Opportunities for business partner reengineering. Journal of Management Information Systems, 11(2), 37-57.

Sager, M. (1998). Competitive Information Systems in Australian retail Banking. Information and Management, 15, 59-67. http://dx.doi.org/10.1016/0378-7206(88)90030-4

Santhanam, R., \& Hartono, E. (2003). Issues in Linking Information Technology Capability to Firm Performance. MIS Quarterly, 27(1), 125-153.

Sarker, S., Sarker, S., \& Sidorova, D. (2006). A. Understanding business process change failure: An actor-network perspective. Journal of Management Information Systems, 23(1), 51-86. http://dx.doi.org/10.2753/MIS0742-1222230102

Scherr, A. L. (1993). A new approach to business processes. IBM System Journal, 32(1), 80-98. http://dx.doi.org/10.1147/sj.321.0080

Sekaran, U. (2003). Research methods for business. New York: John Wiley \& Sons Inc.

Tabachnick, G. B., \& Fidell, S. L. (2007). Using Multivariate Statistics (5th ed.). New York: Pearson Educational Inc.

Tennat, C., \& Wu, Y. (2005). The application of Business process reengineering in the UK. The TQM Magazine, 17, 537-545. http://dx.doi.org/10.1108/09544780510627633

Thong, J., Yap, C., \& Seah, K.-L. (2000). Business Process Reengineering in the public sector: The ease of the housing development board in Singapore. Journal of Management Information Systems, 17(1), 245-270.

Thurstone, L. L. (1947). Multiple factor analysis. Chicago: University of Chicago Press.

Tippins, M. J., \& Sohi, R. S. (2003). IT Competency and firm performance: Is organizational learning a missing link? Strategic Management Journal, 24, 745-761. http://dx.doi.org/10.1002/smj.337

Venkatraman, N., \& Zaheer, A. (1990). Electronic Integration and Strategic Advantage: A Quasi-Experimental Study in the Insurance Industry. Information System Research, 1(4), 377-393. http://dx.doi.org/10.1287/isre.1.4.377

Yavas, U., \& Yasin, M. M. (2001). Enhancing organizational performance in banks: a systematic approach. Journal of Services Marketing, 15(6), 444-453. http://dx.doi.org/10.1108/EUM0000000006099

Zairi, M., \& Sinclair, D. (1995). Business process re-engineering and process management: a survey of current practice and future trends in integrated management. Management Decision, 33(3), 3-16. http://dx.doi.org/10.1108/00251749510085021 
Table 4.1. Response Rate of the Questionnaires

\begin{tabular}{lcccc}
\hline Response & Commercial & Microfinance & Mortgage & Freq/Rate \\
\hline No. of distributed questionnaires & 21 & 449 & 90 & 560 \\
Returned questionnaires & 21 & 349 & 90 & 460 \\
Returned and usable questionnaires & 18 & 312 & 87 & 417 \\
Returned and excluded questionnaire & 3 & 37 & 3 & 43 \\
Questionnaires not returned & 0 & 100 & 0 & 100 \\
Response rate & $100 \%$ & $77.72 \%$ & $100 \%$ & $82.14 \%$ \\
Usable response rate & 86 & $69 \%$ & $97 \%$ & $74 \%$ \\
\hline
\end{tabular}

Source: Developed for the research

Table 4.2. Demographic characteristics of the respondents

\begin{tabular}{|l|ll|l|l|}
\hline S/N & ITEMS & FREQUENCY & PERCENTAGE \\
\hline 1 & Gender: & & \\
& Male & 283 & 67.90 \\
& Female & 134 & 32.10 \\
\hline 2 & Job Title & & \\
& i. ED/GM & 65 & 15.6 \\
& ii. DGM/AGM & 82 & 19.7 \\
& iii. SM/MGR & 125 & 30.0 \\
& iv. HOD & 145 & 34.8 \\
\hline 3 & Category of Bank & & \\
& i. Commercial Bank & 18 & 4.3 \\
& ii. Microfinance Bank & 312 & 74.8 \\
& iii. Primary Mortgage Bank & 87 & 20.9 \\
\hline 4 & Number of employees including outsource in organization & & \\
& i. $\quad 1-50$ employees & 249 & 59.7 \\
& ii. $\quad 51-100$ employees & 35 & 8.4 \\
& iii. 101 - 1000 employees & 53 & 12.7 \\
& iv. 1001 - 2000 employees & 19 & 4.6 \\
& v. Above 2000 employees & 61 & 14.6 \\
\hline
\end{tabular}


Table 4.3. Factor loading and communalities for variables

Dependent Variable:

Organization Performance

\begin{tabular}{|l|c|c|c|c|c|}
\multicolumn{2}{|c}{ Rotated } \\
\hline & \multicolumn{2}{|c}{ Matrix } & & Communalities \\
\cline { 2 - 6 } & 1 & 2 & 3 & Initial & Extraction \\
\hline OP20 & .984 & .054 & .084 & 1.000 & .621 \\
\hline OP18 & .981 & .092 & .083 & 1.000 & .640 \\
\hline OP7 & .981 & .081 & .088 & 1.000 & .636 \\
\hline OP15 & .978 & .080 & .068 & 1.000 & .977 \\
\hline OP13 & .977 & .090 & .089 & 1.000 & .725 \\
\hline OP4 & .094 & .794 & .018 & 1.000 & .698 \\
\hline OP5 & .051 & .785 & .131 & 1.000 & .970 \\
\hline OP3 & .066 & .770 & .155 & 1.000 & .967 \\
\hline OP8 & .114 & .083 & .840 & 1.000 & .979 \\
\hline OP9 & .075 & .180 & .812 & 1.000 & .978 \\
\hline
\end{tabular}

Rotated Component Matrix

Note: major loadings for each item are bolded
Moderating Variable:

I.T Capability

\begin{tabular}{|c|c|c|c|c|c|}
\hline Rotated & Mat & & & & Communality \\
\hline & & Compol & & & Communalities \\
\hline & 1 & 2 & 3 & Initial & Extraction \\
\hline TCAP3 & .754 & .173 & .057 & 1.000 & .602 \\
\hline TCAP5 & .731 & .160 & .281 & 1.000 & .639 \\
\hline ГСАР4 & .730 & .250 & .163 & 1.000 & .621 \\
\hline ГСАР6 & .700 & .226 & .144 & 1.000 & .562 \\
\hline ГСАР8 & .250 & .794 & .126 & 1.000 & .709 \\
\hline ГСАР7 & .256 & .735 & -.001 & 1.000 & .605 \\
\hline ГСАР9 & .196 & .714 & .273 & 1.000 & .623 \\
\hline TCAP11 & .180 & .154 & .759 & 1.000 & .633 \\
\hline ТCAP12 & .261 & -.064 & .749 & 1.000 & .633 \\
\hline ТСАР10 & .028 & .384 & .650 & 1.000 & .571 \\
\hline
\end{tabular}

Rotated Component Matrix

Note: major loadings for each item are bolded 
Table 4.4. Factor loading and communalities for independent variables

\begin{tabular}{|c|c|c|c|c|c|c|c|c|c|c|c|c|}
\hline & \multicolumn{9}{|c|}{ Component } & & $\begin{array}{c}\text { Commu } \\
\text { nality }\end{array}$ & Initial \\
\hline & 1 & 2 & 3 & 4 & 5 & 6 & 7 & 8 & 9 & & $\begin{array}{c}\text { Extracti } \\
\text { on }\end{array}$ & \\
\hline IT INFRA3 & .773 & .036 & .021 & .172 & .114 & -.047 & .128 & -.030 & .019 & CM1 & .968 & 1.000 \\
\hline IT INFRA4 & .755 & .008 & .039 & .168 & -.024 & .073 & .169 & -.039 & .063 & CM2 & .626 & 1.000 \\
\hline EPR2 & .722 & .019 & .059 & -.042 & -.019 & .013 & .172 & .097 & .126 & CM3 & .695 & 1.000 \\
\hline IT INFRA2 & .551 & -.042 & .022 & .370 & .037 & -.074 & .094 & .066 & .288 & CM4 & .967 & 1.000 \\
\hline PROJ1 & -.175 & .754 & .108 & -.033 & .093 & .019 & .055 & -.036 & .068 & CM5 & .607 & 1.000 \\
\hline PROJ4 & .033 & .740 & .092 & .102 & .061 & .031 & .022 & .107 & .032 & CM7 & .524 & 1.000 \\
\hline PROJ3 & .019 & .718 & .031 & -.005 & .004 & .099 & -.053 & .002 & .007 & CM8 & .605 & 1.000 \\
\hline PROJ2 & .167 & .710 & .093 & .166 & .001 & .064 & .107 & -.024 & -.041 & CM9 & .601 & 1.000 \\
\hline CF4 & .061 & .152 & .740 & -.020 & .227 & -.076 & -.003 & -.095 & -.118 & PROJ1 & .630 & 1.000 \\
\hline CF3 & .064 & .095 & .735 & .096 & -.150 & .300 & -.009 & .049 & -.012 & PROJ2 & .586 & 1.000 \\
\hline $\mathrm{CF} 1$ & -.007 & .051 & .734 & .111 & -.186 & .286 & .078 & .084 & -.039 & PROJ3 & .529 & 1.000 \\
\hline $\mathrm{CF} 2$ & .041 & .111 & .728 & -.112 & .236 & -.284 & .045 & -.077 & .166 & PROJ4 & .585 & 1.000 \\
\hline TOPMGT7 & .033 & -.002 & -.034 & .792 & -.029 & .010 & .143 & .063 & .015 & TOPMGT5 & .552 & 1.000 \\
\hline TOPMGT6 & .210 & .124 & .016 & .772 & .053 & -.035 & .144 & -.005 & .088 & TOPMGT6 & .689 & 1.000 \\
\hline TOPMGT5 & .164 & .120 & .091 & .676 & .086 & -.028 & .072 & -.055 & .172 & TOPMGT7 & .655 & 1.000 \\
\hline CM8 & -.053 & .023 & .041 & .030 & .749 & .185 & .003 & .054 & .006 & CF1 & .685 & 1.000 \\
\hline $\mathrm{CM} 2$ & .057 & .029 & .092 & .120 & .719 & .273 & -.013 & .088 & -.002 & $\mathrm{CF} 2$ & .728 & 1.000 \\
\hline CM5 & .101 & .109 & -.066 & -.029 & .705 & .257 & .067 & .032 & .102 & CF3 & .678 & 1.000 \\
\hline CM3 & .056 & .065 & .107 & -.024 & .264 & .767 & -.059 & .114 & .025 & $\mathrm{CF} 4$ & .656 & 1.000 \\
\hline CM9 & .014 & .124 & .061 & .000 & .200 & .728 & -.017 & .102 & .029 & IT INFRA2 & .546 & 1.000 \\
\hline CM7 & -.078 & .042 & .011 & -.060 & .320 & .638 & .042 & -.023 & -.022 & IT INFRA3 & .662 & 1.000 \\
\hline AFR5 & .098 & .024 & .040 & .046 & .158 & -.122 & .761 & .055 & -.090 & IT INFRA4 & .640 & 1.000 \\
\hline AFR4 & .218 & .073 & .036 & .082 & -.059 & .062 & .713 & .055 & .037 & EPR2 & .583 & 1.000 \\
\hline EPR5 & .092 & -.005 & -.013 & .149 & .005 & .019 & .633 & -.007 & .339 & EPR4 & .502 & 1.000 \\
\hline EPR4 & .236 & .027 & .024 & .273 & -.073 & .022 & .544 & .008 & .263 & EPR5 & .547 & 1.000 \\
\hline CM4 & .036 & .032 & -.012 & .011 & .070 & .088 & .052 & .974 & -.014 & AFR1 & .689 & 1.000 \\
\hline CM1 & .024 & .023 & -.021 & .007 & .092 & .100 & .055 & .972 & -.002 & AFR2 & .674 & 1.000 \\
\hline AFR2 & .198 & .002 & -.094 & .055 & -.042 & .058 & .069 & -.007 & .783 & AFR4 & .582 & 1.000 \\
\hline AFR1 & .091 & .077 & .069 & .234 & .168 & -.035 & .210 & -.014 & .736 & AFR5 & .644 & 1.000 \\
\hline
\end{tabular}

Note: major loadings for each item are bolded 
Table 4.5. Tolerance Value and the Variance Inflation Factor (VIF)

\begin{tabular}{lll} 
& \multicolumn{2}{l}{ Collinearity Statistics } \\
\cline { 2 - 3 } Independent variables & Tolerance & VIF \\
\hline (Constant) & .704 & 1.420 \\
IT Investment & .882 & 1.134 \\
Strategy Alignment & .906 & 1.104 \\
Customer Focus & .746 & 1.341 \\
Personnel Commitment & .716 & 1.397 \\
Effective Communication & .697 & 1.435 \\
Training and Education & .711 & 1.406 \\
Volume of Financial Activity & .939 & 1.065 \\
Reward System & .781 & 1.281 \\
Strong Capital base & & \\
\hline
\end{tabular}

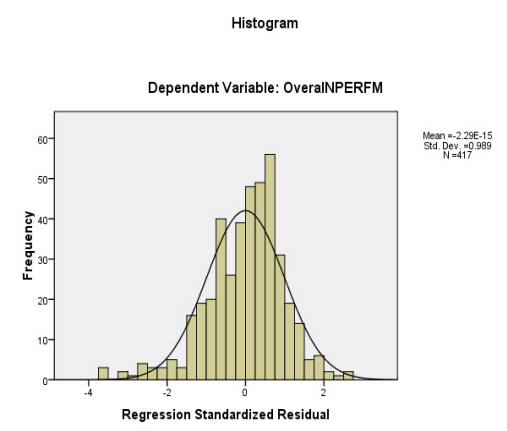

Figure 4.0. Residual plot - BPR factors and organization performance

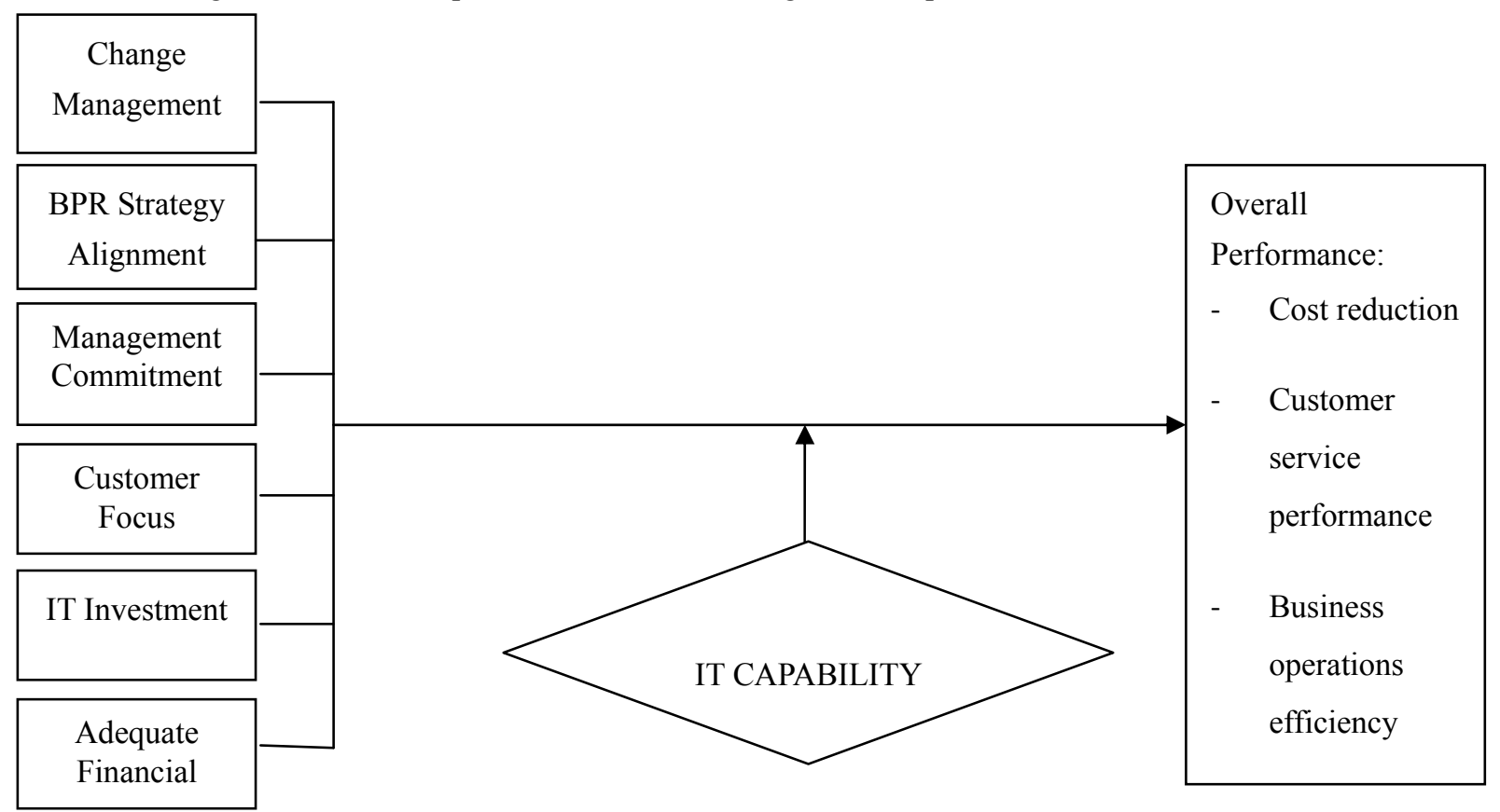

Figure 4.1. Modified research model framework of BPR factors and organization performance 